\title{
ORGANIZATIONAL CULTURE AND INNOVATION: AN EXPLORATORY STUDY IN BRAZILIAN COMPANIES
}

\author{
Lillian do Nascimento Gambi ${ }^{1}$, Fabiane Letícia Lizarelli ${ }^{2}$ and Mateus Cecílio Gerolamo ${ }^{3}$ \\ ${ }^{l}$ Federal University of Viçosa - Campus Rio Paranaíba, MG230 - Km7, Brazil \\ ${ }^{2}$ Federal University of São Carlos, Rodovia Washington Luiz, s/n, Brazil \\ ${ }^{3}$ University of São Paulo-EESC, Avenida Trabalhador São-carlense, 400, Brazil
}

\begin{abstract}
Organizational culture is viewed as an important variable to innovation success; it can stimulate creativity and innovative behavior among employees. Besides, companies have adopted different practices to improve its social aspects into innovation direction. Moreover, the growth of international companies with foreign subsidiaries, forces them to adopt the most effective organizational practices to all business units in order to build a sustainable competitive advantage. In this context, this work uses data from 42 large manufacturing companies located in Brazil to investigate the organizational culture profile and the adoption of organizational innovation practices. Furthermore, uses Kruskal-Wallis Test to investigate if there is difference in the adoption of practices if the companies' headquarters is located in Brazil or abroad. Results show that the characteristics of innovative organizational culture profile called Developmental culture were the less identified, as a result, companies still need to develop characteristics of innovative culture, such as assumption of risks, employees' participation. Among the practices, those related to multidisciplinary teams and high variety in employees' tasks were the most adopted, while job rotation and self-managed team the less adopted. In addition, for most practices, no difference was identified in the adoption if headquarters' is located in Brazil or abroad, supporting the idea that organizational culture is more important driver of innovation than national culture.
\end{abstract}

\section{KEYWORDS}

Organizational Culture, Organizational Innovation, Manufacturing Companies

\section{INTRODUCTION}

Organizational culture is viewed as an important key to innovation success (Buschgens, 2013). In parallel, organizational innovation also called administrative innovation (Kim et al. 2012) is related to the new ideas, methods or systems to improve social structures of an organization. According to Kim et al. (2012), this type of innovation increases the efficiency and effectiveness of managerial processes focusing on the adoption of practices that aim to improve social aspects of organization into innovation direction.

The growth of international companies with foreign subsidiaries forces them to operate in a highly competitive environment. Then, firms have to adopt the most effective organizational practices to all business units in order to build a sustainable competitive advantage (Ahlvik and Bjorkman, 2015). In this context, firms need to simultaneously deal with multiple cultures within organization, increasing international competition, especially from the emerging countries, by improving their production and innovation performance. According to Latukha et al. (2019), emerging economies get more attention nowadays, since many multinational companies allocate their subsidiaries in developing countries.

Besides, Ciabuschi et al. (2012) argue that headquarters has a reasonable possibility of monitoring the innovation process at the subsidiary level through its direct involvement in the process and through different control mechanisms. Latukha et al. (2019) suggest that the host country context is likely to have a considerable impact on the process and outcomes of transmission of practices from headquarters to subsidiaries. Then a question emerges in this context: Is there difference in the adoption of organizational innovation practices by the companies if their headquarters is located in Brazil or abroad? 
Therefore, considering that to know the characteristics of organizational culture is important to foster innovation in the firms, the main purpose of this study is, first, to identify the organizational culture profile in large manufacturing companies located in Brazil and the adoption of organizational innovation practices; and, afterwards, to test if there is difference on this adoption if headquarters is located in Brazil or abroad.

\section{RESEARCH METHOD}

To accomplish the purpose it was performed a survey research in an exploratory approach. Data was obtained from a web based questionnaire e-mailed through SurveyMonkey® software to a random sample of 72 Brazilian manufacturing companies. Organizational culture was operationalized based on the Competing Values Framework (CVF) presented by Cameron and Quinn (2006), this framework classifies culture in four profiles: Developmental, Group, Rational or Hierarchical.

Organizational innovation related to innovation personnel practices were operationalized in 8 items adapted from the studies of Vázquez-Bustelo et al. (2007) and measured on a five-point Likert scale ranging from 1 = "low degree of application" to 5 = "high degree of application".

Descriptive analysis was performed in the IBM SPSS Statistics v. 24 to study the organizational culture profile and the personnel innovation practices used by the firms in an exploratory approach. Afterwards, a non-parametric Kruskal-Wallis test was used to investigate if there was difference between the practices used for the companies with headquarters located in Brazil, and companies with headquarters located abroad.

\section{FINDINGS}

As organizational culture profile, the Group and Rational culture were the most frequent organizational culture profile found in the sampled firms, $41 \%$ and $38 \%$, respectively. This result can be explained based on the prevailing assumption behind strategic human resource management: superior performance and competitive advantage are achieved through exploitation of human capital in the company (Singh et al., 2012), then the characteristics of Group culture such as employee involvement, commitment and empowerment were the most common. The Rational Culture, in turn, has as core values competitiveness and productivity, with results, bottom-line results, stretch targets as main objectives of the organization. The assumptions of this culture are that external environment is hostile and firms have to increase its competitive position. Main characteristics of Hierarchical culture were found in $14 \%$ of the companies. Even though the Developmental culture is characterized by entrepreneurship, dynamism and creativity, that is, the profile that would fit better the called "innovation culture", few companies $(7 \%)$ have characteristics of this profile.

Additionally, it is possible to state that practices more related to multidisciplinary teams and high variety in employees tasks were the most used in the companies. Conversely, the practices related to the employees rotation among different activities, task position and self-managed teams with decision making capacity were the less adopted.

Furthermore, this study investigates if the headquarters location influences the adoption of administrative innovation practices. Results of the non-parametric test using de Kruskal-Wallis show that there is no significant $\mathrm{p}$-value $(\mathrm{p}<0.1)$ for seven practices, that is, there is no significant mean difference between groups. However the p-value for the practice: "Incentives for the team, not only for individuals" is significant at 0.025 , then, there is a significant mean difference between where the headquarters is located and the adoption of this practice.

\section{CONCLUSION}

The study shows that companies still need to develop characteristics of innovation culture such as assumption of risks, employees' participation, creativity and shared responsibility, since the Developmental Culture was the profile less identified in the companies sampled. Due to stronger competition environment, firms is still being conservatives in their strategies focusing on the control instead of flexibility, and stretch targets as main 
objectives of the organization, consequently the Rational culture profile was the second most frequent culture profile among the companies studied.

Among the practices, those related to multidisciplinary teams and high variety in employees' tasks were the most adopted, accordingly characteristics of Group culture were identified in most companies. In turn, employee rotation amongst different activities and tasks; and self-managed team were the practices less adopted by the companies, showing that firms should have an emphasis on strategies regarding empowerment, shared responsibilities and a job rotation plan.

In addition, for most practices, no differences were identified in their adoption if headquarters' is located in Brazil or abroad. This can be explained by the fact that organizational culture has a stronger influence in the organizational practices than the national culture. Finally, it is necessary managers willing to know the characteristics of organizational culture and develop those that lead to improve innovation in companies.

\section{ACKNOWLEDGEMENT}

The authors thank the financial support provided by Fundação de Amparo à Pesquisa de Minas Gerais (FAPEMIG) and Conselho Nacional de Desenvolvimento Científico e Tecnológico (CNPq).

\section{REFERENCES}

Ahlvik, C.; Björkman, I., 2015. Towards explaining subsidiary implementation, integration, and internalization of MNC headquarters HRM practices, International Business Review. Vol. 24, No. 3, pp 497-505.

Büschgens, T. et al. 2013. Organizational culture and innovation: a meta-analytic review. International Journal of Product Innovation Management. Vol. 30, No. 4, pp. 763-781.

Cameron, K. S. and Quinn, R. E., 2006. Diagnosing and Changing Organizational Culture: Based on the Competing Values Framework, Jossey-Bass, San Francisco, CA.

Ciabuschi, F. et al. 2012. Headquarters involvement and efficiency of innovation development and transfer in multinationals: a matter of sheer ignorance? International Business Review. Vol. 21, No. 2, pp 130-144.

Kim, D.Y., Kumar, V. \& Kumar, U. 2012. Relationship between quality management practices and innovation. Journal of Operations and Management, Vol. 30, No. 4, pp 295-315.

Latukha et al. 2019. Human resource management practices transferring from foreign firms to Russia: the case of MNCs subsidiaries. Journal of Business Research (article in press), https://doi.org/10.1016/j.jbusres.2019.03.020

Vásquez-Bustelo, D., Avella, L. and Fernández, E. 2007. Empirical test of an integrated agile manufacturing model. International Journal of Operations \& Production Management, Vol. 27, No 12, pp. 1303-1332. 